\title{
Care as Everyday Peacebuilding
}

Analyses of everyday peace provide a critical response to existing peace practices. However, absent from these discussions is the feminist research that theorizes peace through everyday practices of care. We argue that contemporary debates on everyday peace should engage with this largely forgotten tradition. We explore the contributions of this research through case studies that span the north-south divide: from Northern Ireland to Aceh, and Kashmir to Reykjavik. Demonstrating how care is an essential ingredient of everyday peace, we suggest that a care lens allows us to reframe the understanding of everyday peace to provide a fuller picture that also addresses the complex and contradictory nature of social relations involved in everyday peacebuilding. By resolving conflicts over immediate care needs and building the capacity of communities in ways that subtly challenge the fixity of conflict, care cumulatively creates possibilities for peaceful transformation.

Keywords: care; everyday peace; trust; social transformation; feminist peace research 


\section{Care as Everyday Peacebuilding ${ }^{1}$}

Tiina Vaittinen ${ }^{\mathrm{a} *}$, Amanda Donahoe ${ }^{\mathrm{b}}$, Rahel Kunz ${ }^{\mathrm{c}}$, Silja Bára Ómarsdóttir ${ }^{\mathrm{d}}$, Sanam Roohi ${ }^{\mathrm{e}}$

${ }^{a}$ Faculty of Social Sciences, University of Tampere, Tampere, Finland; ${ }^{b}$ Peace and Justice Studies, Tufts University, Boston, US/Centenary College, US; ${ }^{c}$ Faculty of Social and Political Sciences, University of Lausanne, Lausanne, Switzerland; ${ }^{d}$ Faculty of Political Science, University of Iceland, Reykjavik, Iceland ${ }^{e}$ Department of Political Science, St. Joseph's College (Autonomous), Bangalore, India/Max Weber Kolleg in the University of Erfurt, Germany

*Linna Building, 6068, FIN33014 University of Tampere, tiina.vaittinen@uta.fi

Funding details. The coauthoring of the article was made possible by NOS-HS Workshop Grant number 201500127, for the establishment of Feminist Peace Research Network. In addition, Vaittinen's research was made possible by the Academy of Finland (grant number 297053), and Kunz' research was supported by the Swiss Agency for Development and Cooperation and the Swiss National Science Foundation (grant number 400240).

Disclosure statement. The work involves no conflicts of interest.

\section{Biographical notes:}

Tiina Vaittinen is a postdoctoral researcher in Tampere Peace Research Institute TAPRI, Tampere University, Finland. She examines dimensions of peace through questions of care, migration, biopolitics, embodiment, and global health. She has published in journals such as International Feminist journal of Politics and Women's Studies International Forum.

Amanda Donahoe was working as a lecturer of Peace and Justice Studies in Tufts University, US, at the time of writing this manuscript, and now works as Assistant Professor of Political Science in Centenary College, US. She is the author of Peacebuilding through Women's Community Development: Wee Women's Work in Northern Ireland (Palgrave, 2017).

Rahel Kunz is a senior lecturer at the Institute of Political, Historical and International Studies of the University of Lausanne, Switzerland. Her research draws on feminist poststructuralist and postcolonial

${ }^{1}$ Note on the order of authors: The theoretical frame of the article draws on Tiina Vaittinen’s PhD thesis, and hence we have placed Tiina as the first author. Otherwise, the article is a product of co-authorship, with the authors introduced in alphabetical order. For the case studies, Amanda Donahoe draws on her expertise and empirical materials on Northern Ireland, Rahel Kunz on Aceh and Silja Bára Ómarsdottir on Iceland and Sanam Roohi on Kashmir. We are thankful for the Feminist Peace Research Network workshops, funded by NOS-HS, for bringing us together to write this piece, and for the network members for comments on the draft versions of the manuscript. We also thank the editors of this special issue, Laura Mcleod and Maria O'Reilly, and for their very helpful comments and support during the publication process. 
theories to focus on gender issues in migration and development, and conflict and security. She has published in various journals and is the author of The Political Economy of Global Remittances: Gender, Governmentality and Neoliberalism (Routledge 2011).

Silja Bára Ómarsdóttir is an associate professor at the University of Iceland's Faculty of Political Science. She holds a PhD in Politics from University College Cork and works on Iceland's foreign and security policy, feminist international relations, as well as reproductive rights.

Sanam Roohi worked as Assistant Professor in Department of Political Science, St. Joseph's College (Autonomous), Bangalore, India, at the time of writing this article. She now works as a postdoctoral COFUND Fellow at Max Weber Centre for Advanced Cultural and Social Studies, University of Erfurt, Germany. She holds a PhD from the University of Amsterdam, the Netherlands, and has published in journals such as Journal of Ethnic and Migration Studies and Modern Asian Studies. 


\section{Introduction}

A tradition focusing on everyday peace is emerging in contemporary Peace and Conflict Research. ${ }^{1}$ Related to the 'local turn'2 and contributing to 'post-liberal peacebuilding', this literature develops understandings of how 'simple everyday activities present the realm of the possible ${ }^{3}$ in situations where conflicts within or between social groups are ongoing, or are likely to erupt. ${ }^{4}$ Examining people’s lived experiences of conflicts, the everyday peace literature grows from a critique of liberal approaches to peacebuilding, ${ }^{5}$ criticised for limiting their attention to institutions, while 'sacrificing concern for

${ }^{1}$ E.g. Roger Mac Ginty, 'Everyday Peace: Bottom-Up and Local Agency in Conflict-Affected Societies’, Security Dialogue 45:6 (2014), 548-564; Pamina Firchow and Roger Mac Ginty 'Measuring Peace: Comparability, Commensurability, and Complementarity Using Bottom-Up Indicators’, International Studies Review 19 (2017): 6-27; Oliver Richmond, A Post-Liberal Peace. Routledge: London (2011); Roger Mac Ginty and Oliver P. Richmond, 'The Local Turn in Peacebuilding: A Critical Agenda for Peace', Third World Quarterly 34:5 (2013), 763-783; Helen Berents, 'An Embodied Everyday Peace in the Midst of Violence', Peacebuilding 3:2 (2015), 1-14; Sukanya Podder, 'The Power In-Between: Youth’s Subaltern Agency and the Post-Conflict Everyday', Peacebuilding 3:1 (2014), 36-57; Laura McLeod, 'Feminist Approach to Hybridity: Understanding Local and International Interactions in Producing Post-Conflict Gender Security’, Journal of Intervention and Statebuilding 9 (2015), 48-69; Gearoid Millar, 'For Whom Do Local Peace Processes Function? Maintaining Control through Conflict Management', Cooperation and Conflict 52:3 (2017), 293-308; Elisa Randazzo, 'The Paradoxes of the "Everyday”: Scrutinising the Local Turn in Peace Building', Third World Quarterly, 1-20 (2016); Christelle Rigual, 'Rethinking the Ontology of Peacebuilding. Gender, Spaces and the Limits of the Local Turn’, Peacebuilding 6:2 (2018); Tarja Väyrynen, 'Mundane Peace and the Politics of Vulnerability: A Nonsolid Research Agenda', in this issue.

${ }^{2}$ See for example Rachel Julian, Berit Bliesemann de Guevara and Robin Redhead, 'From Expert to Experiential Knowledge: Exploring the Inclusion of Local Experiences in Understanding Violence in Conflict', this issue.

3 Podder (2015), 56.

${ }^{4}$ Mac Ginty (2014), 549.

${ }^{5}$ See Susanna Campbell, David Chandler, and Meera Sabaratnam. A Liberal Peace?: The Problems and Practices of Peacebuilding. Zed Books (2011) ; John Heathershaw 'Unpacking the Liberal Peace: The Dividing and Merging of Peacebuilding Discourses’. Millennium 36:3, 597-621 (2008). 
community, local needs, and everyday experience. ${ }^{6}$ The everyday peace literature emphasises social practices and 'bottom-up, localized and particularistic conflictcalming measures,' thus going beyond negative peace as an absence of war, and 'towards everyday diplomacy or people-to-people activities that can move a society towards conflict transformation., ${ }^{7}$

Despite its important openings, the contemporary everyday peace literature ignores many feminist accounts of the everyday, ${ }^{8}$ including a rich tradition that theorises peace and conflict through the ethics of care. ${ }^{9}$ For instance, the Everyday Peace Indicators (EPI) project, by Pamina Firchow and Roger Mac Ginty, has mapped a

\footnotetext{
${ }^{6}$ Berents (2015), 191.
}

${ }^{7}$ Mac Ginty (2014), 549. See also Stefanie Kappler and Nicolas Lemay-Hébert, 'From Power-Blind Binaries to the Intersectionality of Peace: Connecting Feminism and Critical Peace and Conflict Studies', in this issue.

8 Juanita Elias and Adrienne Roberts, 'Feminist Global Political Economies of the Everyday: From Bananas to Bingo’, Globalizations 13:6 (2016), 787-800.

${ }^{9}$ E.g. Sara Ruddick, Maternal Thinking: Towards a Politics of Peace. (New York: Ballantine Books, 1990); Joan C. Tronto, Moral Boundaries: A Political Argument for an Ethic of Care. (New York and London: Routledge, 1993); Linda Rennie Forcey, 'Women as Peace Makers. Contested Terrain for Feminist Peace Studies', Peace and Change 16:4 (1991), 331-354; Alison Bailey, 'Mothering, Diversity and Peace Politics’, Hypatia 9:2 (1994), 188-198; Fiona Robinson, Globalizing Care: Ethics, Feminist Theory, and International Relations. (Westview Press: Boulder, 1999); Fiona Robinson, The Ethics of Care: A Feminist Approach to Human Security. (Temple University Press: Philadelphia, 2011); Sigal Ben-Porath, ‘Care Ethics and Dependence: Rethinking Jus Post Bellum”, Hypatia 23:2 (2008), 61-71; Virginia Held, The Ethics of Care: Personal, Political and The Global, (Oxford University Press: Oxford and New York, 2006); Kimberly Hutchings, 'Towards Feminist International Ethics”, Review of International Studies 26 (2000), 111-130; Carol Cohn ، "Maternal Thinking” and the Concept of Vulnerability in Security Paradigms, Policies and Practices”, Journal of International Political Theory 10:1 (2014), 46-69; Fiona Robinson and Catia Confortini 'Symposium: Maternal Thinking for International Relations? Papers in Honor of Sara Ruddick', Journal of International Political Theory 10:1 (2014), 38-45; Hannah Partis-Jennings, 'The “Third Gender” in Afghanistan: A Feminist Account of Hybridity as a Gendered Experience', in this issue; Väyrynen, in this issue; Keppler and Lemay-Hébert, in this issue. 
wide range of indicators for measuring everyday peace, many of which point to dimensions of care and caring. ${ }^{10}$ However, the EPI project is yet to engage with existing peace theories on everyday practices of care. In general, as shown by Vaittinen elsewhere, the contemporary critical peace studies tend to ignore this feminist tradition. ${ }^{11}$ This is glaring, since different kinds of care needs are present in all contexts of human life, including situations of conflict and peacebuilding.

When care is not explicitly addressed in analyses of peace, it follows that various mundane practices of caring that are crucial in creating trust and peaceful conflict transformation are either taken for granted, or remain invisible. Consequently, the intricate processes of everyday peacebuilding are not fully understood. We address this gap by examining different conflicts through a care lens, which provides a critical understanding of conflict management and peacebuilding that goes beyond the dominant accounts of everyday peace. The care lens reframes our understanding of peace, by providing a fuller picture of the complex and contradictory nature of building and sustaining social relations involved in peacebuilding.

Our aim in the article is not to add a new code for caring to the indicators for everyday peace, however. Nor do we suggest that feminist theories of care should replace other approaches to everyday peace. Rather, we want to emphasise that care, and the gendered power relations that go with it, cut through social practices in all

\footnotetext{
${ }^{10}$ Among the indicators are codes such as social cohesion and interdependence, education, access to health care, routine for social practices, conflict resolution, and so on - many of which found in feminist peace literature on care. See Everyday Peace Indicators Project: 'Codebook - EPI Categories - May 2016', https://everydaypeaceindicators.org/research/ (accessed 18 May, 2018).

${ }^{11}$ For a detailed discussion and examples, see Tiina Vaittinen, The Global Biopolitics of Needs: Transnational Entanglements Between Ageing Finland and the Global Nurse Reserve of the Philippines, Tapri Studies in Peace and Conflict Research 103 (Tampere: TAPRI, 2017), http://urn.fi/URN:ISBN:978-952-03-0505-5, 51-64, 158-161.
} 
contexts of peace and conflict. For the understanding of everyday peace, engaging with feminist theories of care is therefore crucial.

As we show in this article, everyday practices of care not only sustain life through direct acts of care-giving, but in various gendered ways involving caring human beings they also sustain and help to build trust among and within communities. They open the potential for peaceful transformation in circumstances, where such transformation seems unlikely if not impossible. In conflict and post-conflict societies, possibilities for peace thus emerge from non-linear cycles of care, trust, and transformation. ${ }^{12}$ Simultaneously, given the detailed insights of feminist care literature into the power dimensions of care, the care lens avoids romanticising everyday peace, allowing for an alternative gendered reading of peace and peaceful transformations.

In what follows, we briefly revisit the feminist peace research tradition that addresses care, after which we show through four case studies how different dimensions of care contribute to everyday peace, and what a reading of peacebuilding through a care lens reveals. Our case studies range from the Troubles in Northern Ireland to 'postconflict' Aceh to conflict-ridden Kashmir to the financial crisis in Iceland. We have selected a disparate sample of case studies in order to demonstrate the ways in which care in its multiple dimensions emerges as a site, source, and catalyst of everyday peace in different conflict contexts. ${ }^{13}$ We do not seek to provide a uniform or exhaustive

\footnotetext{
12 This resonates with debates around the potential of non-linear understandings of peacebuilding (see Chandler, D. (2013) ‘Peacebuilding and the politics of non-linearity: rethinking 'hidden' agency and 'resistance'”. Peacebuilding, 1:1, 17-32.

${ }^{13}$ The article builds on our discussions in the first Feminist Peace Research Network (FPRN) Workshop in Tampere, June 2016, where care as everyday peacebuilding in different conflicts turned out to be a common theme from our disparate fieldwork experiences. For FPRN, see: http://www.uta.fi/yky/en/feministpeaceresearch/index.html.
} 
account of care as a means for peaceful transformation, or a comparative analysis.

Rather, we ask how and what kind of care is present, and what relations of care do for everyday peace and the potential for transformation in conflict or post-conflict societies. Such questions, we suggest, should become a standard practice in all analyses of everyday peacebuilding.

\section{Care as Peacebuilding}

The contemporary everyday peace literature challenges theories and practices of liberal peacebuilding. ${ }^{14}$ Since the 1980 s, feminist care and peace theorists have done something very similar, by drawing attention to the situated necessities of care and human relatedness that liberal abstractions of political subjectivity tend to ignore. This feminist literature maintains that practices of care give rise to distinct moral and political thinking, which derives from the existential fact of human vulnerability and relatedness, and the capacity to recognise and respond to the needs of others. ${ }^{15}$ Such alternative moral thinking, care ethicists argue, is capable of challenging militarism and the customary thinking of global justice, while providing avenues for re-imagining just peace. $^{16}$

In her pioneering book Maternal Thinking, ${ }^{17}$ Sara Ruddick for instance argued that the thinking that arises from mothering may be used as a 'standpoint from which to criticize the destructiveness of war and begin to reinvent peace. ${ }^{18}$ Despite some

\footnotetext{
${ }^{14}$ See fn. 1 and 4.

15 See fn. 8.

${ }^{16}$ Catia C. Confortini and Abigail Ruane, 'Sara Ruddick’s Maternal Thinking as Weaving Epistemology for Justpeace', Journal of International Political Theory 10:1(2014), 70-93.

${ }^{17}$ Ruddick (1990). For discussion, Robinson and Confortini (2014); Vaittinen (2017), 51-55; Väyrynen, this issue.

${ }^{18}$ Ruddick (1990), 12.
} 
interpretations to the contrary, ${ }^{19}$ mothers and maternal thinking in this account do not refer to 'women' but to any 'responsible adult', who 'takes on responsibility for children's lives and for whom providing child care is a significant part of her or his working life. ${ }^{20}$ As Ruddick’s maternal thinking, feminist care ethics also more generally goes beyond the understanding of care as 'women's' reproductive labour. ${ }^{21}$ Whereas the term 'care' in popular parlance carries connotations of feminised kindness that comes out 'naturally', especially from 'women', care ethicists recognise care as a field of complex political struggle. They acknowledge that care relations are power relations, imbued with the potential of dominance, exploitation, and even direct violence - and difficult choices as to whose care needs matter. ${ }^{22}$

For care ethicists then, care practices give rise to situated, embodied ethics, and mundane practices of conflict management. This understanding unsettles the more abstract frameworks of liberal peacebuilding that emphasise institutions and universalist solutions. In this regard, feminist ethics of care presented a theory of 'post-liberal' peace well before the contemporary accounts of the same. ${ }^{23}$ Simultaneously, the care lens provides a more nuanced picture of social relations that goes beyond a romanticised understanding of care and empathy. It challenges dichotomous representation of liberal

${ }^{19}$ E.g.: Laura Duhan Kaplan 'Woman as Caretaker: An Archetype that Supports Patriarchal Militarism’, Hypatia 9:2 (1994), 123-133; Tarja Väyrynen, 'Gender and peacebuilding', in Palgrave Advances in Peacebuilding: Critical Developments and Approaches ed. Oliver P. Richmond, (Basingstoke and New York: Palgrave Macmillan, 2010), 137-153.

${ }^{20}$ Ruddick (1990), 40, 41.

${ }^{21}$ E.g., Tronto (1993); Tiina Vaittinen, 'The Power of The Vulnerable Body: A New Political Understanding of Care', International Feminist Journal of Politics, 17:1 (2015), 100-118.

22 E.g. Robinson (1999), 128; Robinson (2011), 5.

${ }^{23}$ E.g. Richmond (2011). 
versus non-liberal and rationality versus empathy, questioning some of the tendencies in the post-liberal peace literature. ${ }^{24}$

The largely forgotten tradition of feminist peace research that focuses on care asks us to scrutinise the situated and often difficult peacebuilding work that gendered relations of care and caring do in conflict-prone situations, beyond inter-personal practices of caregiving. Here, care is understood as a form of social and corporeal relatedness, enacted by the moral and political demands of care by human beings who are, by default, vulnerable and dependent on multiple others within the society. ${ }^{25}$ Consequently, relations and practices of care cut through, and are conditioned by, the entire social strata, tying together social structures beyond the inter-personal and intimate practices of caregiving, as our case studies below demonstrate. ${ }^{26}$

\section{Northern Ireland: Care as community-building and peacebuilding ${ }^{27}$}

From the late 1960s until the Good Friday Agreement in 1998, Northern Ireland experienced political violence known as the 'Troubles,' between 'Catholics' and 'Protestants'. ${ }^{28}$ What began as a non-violent civil rights movement, transformed into a

\footnotetext{
${ }^{24}$ Richmond, Oliver P. (2009), 'Becoming Liberal, Unbecoming Liberalism: Liberal-Local Hybridity via the Everyday as a Response to the Paradoxes of Liberal Peacebuilding', Journal of Intervention and Statebuilding, 3:3, 324-344.

${ }^{25}$ See also Väyrynen, this issue.

${ }^{26}$ Cf. Berenice Fisher and Joan C. Tronto, 'Toward a Feminist Theory of Caring', in Circles of Care: Work and Identity in Women's Lives ed. Emily K. Abel and Margaret K. Nelson (State University of New York Press: Albany, 1990), 35-61; Tronto (1993); Vaittinen (2015).

27 This section draws on fieldwork carried out by Amanda E. Donahoe in Northern Ireland from JulyDecember 2012. Semi-structured interviews, focus groups and ethnographies were conducted along both sides of the social divide.

${ }^{28}$ Use of the terms 'Protestant' and 'Catholic' in Northern Ireland are placeholders for more complex clusters of political identities including British, Unionist, or Loyalist in the case of 'Protestant'; and
} 
violent contest over the ‘constitutional question': should Northern Ireland remain part of the United Kingdom or instead unite with Ireland? In 1972, following increasing levels of violence, the local Stormont Government was disbanded in favour of direct rule. The ensuing political vacuum was filled by the violence of the Troubles on the one hand, and the necessary caring efforts of community-building on the other. The 'community and voluntary sector' that thereby emerged contributed to everyday peace in the midst of violence, and remains critical for peacebuilding in Northern Ireland. ${ }^{29}$ With seventyfive percent of paid positions in the community and voluntary sector being held by women in Northern Ireland, ${ }^{30}$ our first case study draws attention to women's role in community-building.

Building on Ruddick’s work, Catia Confortini and Abigail Ruane argue that '[f]or mothers, the relationship with the other is a condition for knowing the world' ${ }^{31}$ For women in Northern Ireland, caring relationships within the community and across communal divides became a condition for knowing the Troubles in ways that allowed spaces of everyday peace to emerge. On both sides of the divide, women formed groups to meet the needs of their families and neighbours, confronting overlapping forms of deprivation created by the conflict and a failing economy. Knowing the conflict was thus mediated through the care needs of others that ensued from the violence. On both sides of the conflict, women saw children being caught up in paramilitaries and sought

Irish, Nationalist, or Republican in the case of 'Catholic.' However, as these terms are commonly used in Northern Ireland, they will suffice here.

${ }^{29}$ Amanda E. Donahoe, Peacebuilding through Women's Community Development: Wee Women's Work in Northern Ireland (New York: Palgrave Macmillan, 2017).

${ }^{30}$ NICVA, 'Working Patterns by Gender', in State of the Sector: Workforce Chapter. (DetailData:

Northern Ireland Community and Voluntary Association, 2014).

${ }^{31}$ Confortini and Ruane (2014), 73. 
to occupy them in play schemes and after school programs. They saw their families and neighbours' families suffering from hunger, and developed urban gardening, nutrition, and catering projects. They saw violence in their own homes and sought to protect each other by locating safe spaces, legal support, and health and counselling services. To achieve their goals, they sought various forms of training and education, from primary education and childcare to grant writing and project development. They professionalized and challenged gender dynamics in their communities.

The operation of women's community groups on both sides of the divide is an example of care as societal healing, a crucial dimension of peacebuilding. An important aspect in their work is networking across the communal divide, extending care to the side of the other. The Catholic Falls Women's Centre, for instance, one of the first in Belfast, helped the Protestant Shankill Women's Centre get organized to care for the women of its community, despite the fact that these two centres are located on either side of one of the most well-known interfaces in Belfast. Thus, women who could have identified as enemies engendered trust. Years later, when funding was denied to the Falls Women's Centre amid accusations that they were politically associated with the violence, the Shankill Women fortified this trust by standing with the Falls Women and calling on the city to grant the funding.

The collaboration of these two centres is unexceptional. Managers and organizers of women’s centres across Northern Ireland regularly share best practices and collaborate on projects and funding applications. They belong to and utilise resources of umbrella groups like the Women’s Support Network, or the Women’s Resource and Development Agency. This network contributes to the standardization of women's centres such that similar classes, trainings, and services are available across Northern Ireland. These collaborations not only help build resources to care for the 
members of individual communities, but the shared practices and knowledges continue to foster peaceful relations across the communal divides.

Thus, the ethics of care that was born from recognising the everyday care needs within one’s own community has, over time, fostered collaboration, trust, and care across communities. For instance, women attend events or weekend 'residentials,' in which they engage with the 'other', share stories and work on joint projects. Though women who participate in residentials rarely directly challenge power relations that reinforce the communal divide in their own communities, these experiences foster relational awareness and compassion, which keeps such prospects open for the future. Relating concretely with the other transforms women's community politics, as women identify needs in common rather than in competition with their acquaintances from the other community. This compassion is extended, for example, when they moderate children's slurs against the other. Thereby, the relational logic of knowing the Troubles through the everyday needs of the 'other' - and not only through the 'other's' violence - continues to foster a peaceful transformation.

The case of community development in Northern Ireland demonstrates how a care lens allows us to account for activities and social relations that are essential to everyday peacebuilding across communities. However, care is not necessarily ‘women’s work'; the maternal practices of knowing conflicts through the needs of the 'other' takes many forms. In the following section, we illustrate this through the care practices of mostly male leaders in Aceh. 


\section{Aceh: village leader's caring and everyday acts of kindness as peacebuilding ${ }^{32}$}

Since shortly after Indonesian independence in 1945, Aceh’s politics have been dominated by calls for independence from Indonesia, leading to repeated armed insurrections. ${ }^{33}$ From 1976 to 2005, the independence movement in the form of the Free Aceh Movement (Gerakan Aceh Merdeka, GAM) waged an armed struggle against the central government, which ended with the signing of a peace agreement that granted Aceh wide-ranging political autonomy. ${ }^{34}$ The desire for independence is a complex matter, motivated among other things by issues of economic disparity, political subordination, and differing understandings of Islam. ${ }^{35}$

During the thirty years of conflict, Acehnese people found themselves in various positions, in between the Indonesian military and GAM, drawn into supporting GAM, or trying to remain neutral, or doing both. In the conflict literature, civilian populations are often perceived as passive victims of armed violence. In Aceh, many civilians took active roles in conflict, defying notions of victimhood. Various forms of mediation,

32 This case study draws on research carried out by Rahel Kunz in the context of a collective project Gender Dimensions of Social Conflicts, Armed Violence and Peacebuilding, supported by the Swiss Programme for Research on Global Issues for Development co-funded by the Swiss Agency for Development and Cooperation and the Swiss National Science Foundation (400240). Inspiring collaboration with Mimidoo Achakpa, Henri Myrttinen, Joy Onyesoh, Elisabeth Prugl, Arifah Rahmawati, Christelle Rigual and Wening Udasmoro is gratefully acknowledged. The case study draws on interview and focus group discussion material collected in 2015-2016. Special thanks go to the data collectors Arifah Rahmawati, Raihal Fajri, Wening Udasmoro and Tabrani Yunis and the respondents. Pseudonyms are used to guarantee anonymity.

${ }^{33}$ Edward Aspinall, Islam and Nation: Separatist Rebellion in Aceh, Indonesia. (Stanford: Stanford University Press, 2009), http://www.eastwestcenter.org/publications/islam-and-nation-separatistrebellion-aceh-indonesia.

${ }^{34}$ M. Amin Zuhri, Membayangkan Aceh Sebagai Negara Bangsa: Sejarah Gerakan Nasionalisme Lokal (PhD dissertation, Yogjakarta: Universitas Gadjah Mada, 2015).

${ }^{35}$ Rizal Rizal Sukma, Security Operations in Aceh: Goals, Consequences, and Lessons, (Washington,

D.C.: Easte-West Center, 2004). 
reconciliation and healing played a key role in negotiating conflict situations and building peace. Communities and individuals mobilised their resources and social positions for conflict de-escalation and peacebuilding, during and after the conflict. ${ }^{36}$ These, we argue, should be understood as practices of care that happened mostly from the bottom up as a micro-politics, involving thousands of leaders of villages, clans, churches, mosques, and community members. ${ }^{37}$

In Acehnese communities, important roles are performed by a few key figures, mostly men. These include the village chiefs (Keuchik), adat cultural figures (Tuhapeut), religious figures (Tengku), and sometimes also (male) youth leaders. During the conflict these figures played an important role in protecting villagers, preventing the escalation of violence or reducing its effects, meditating between the community, the Indonesian military and GAM, and building peace. A community in East Aceh, in one of the most conflict-affected regions with a strong GAM presence, remained comparatively peaceful during the conflict and became a place of refuge for surrounding villages. ${ }^{38}$ In this community, the keuchik and a tengku carried out numerous practices of care, managing to build trust. For instance, both reportedly used their personal material and social capital to negotiate with the GAM and the Indonesian military to free suspected GAM members detained by the Indonesian military. ${ }^{39}$ As one community member reports, the keuchik sold one of his houses to use the money to

\footnotetext{
${ }^{36}$ Rahel Kunz, Henri Myrttinen, Wening Udasmoro, 'Preachers, pirates and peace-building: Examining non-violent hegemonic masculinities in Aceh', in Asian Journal of Women's Studies, 24:3 (2018).

37 John Braithwaite, 'Traditional Justice', in Restorative Justice, Reconciliation, and Peacebuilding, ed. Jennifer J. Llewellyn and Daniel Philpott (Oxford: Oxford University Press, 2014), 225; Jacqueline Aquino Siapno, 'Living through Terror: Everyday Resilience in East Timor and Aceh.' Social Identities 15:1 (2009), 58.

${ }^{38}$ Focus Group Discussion, March 2016.

${ }^{39}$ Ibid
} 
protect the community: he would check on the village even during the night and if a community member was taken away by the GAM or the military, he would use his resources to free them, without taking sides in the conflict. ${ }^{40}$

The tengku turned the space of his house and the mosque in front of it into a safe space, where men could come and pray or even mediate conflict. ${ }^{41}$ When social gatherings were strictly forbidden, and men’s mobility was sometimes even more restricted than women's, due to the military's suspicions that they might be GAM members, these religious gatherings allowed men to meet up with friends, fostering the maintenance of everyday social relations within the community. These acts of care fostered relations of trust among inhabitants of the community, and between the community, the GAM, and the military. Through a cycle of trust and transformation then, caring practices contributed to a transformation of the relationships between the community and the armed actors, which de-escalated the situation in the everyday.

The caring practices of these male leaders could be read as a story of patriarchal practices of leadership, reproducing gendered power relations. Yet, reading them through a lens of care - and not only as patriarchy - can help us better comprehend the work that different kinds of gendered care relations do for everyday peace, and how caring, while gendered, contributes to everyday peace in all its forms. Indeed, the acts of care that helped to transform relationships in peaceful ways in Aceh were never limited to community leaders. The everyday care work of women continued to sustain lives and communities during the conflict. In addition, different kinds of everyday acts

\footnotetext{
40 Ibid.

${ }^{41}$ Interview with Mana, March 2016. It has to be noted, however, that the gatherings in his house were sometimes also used by the Indonesian military to verify who was present and thus presumed as not associated with GAM.
} 
of kindness occurred. For instance, offering a ride to a community member of another religion, or 'the loan of a Muslim-owned lawn mower to cut the grass of the Christian church'42 helped to bring people closer, transforming assumptions about the 'other' and building trust.

Similarly, community rituals contributed to bringing people closer and transforming assumptions about and reconciling with the 'other' ${ }^{43}$ Peusijuek ceremonies, for instance, were used to prepare conflicting parties for negotiations, to bless conflict victims, or to reintegrate returned GAM members. ${ }^{44}$ These caring rituals facilitated dialogue between conflicting parties and the transition of combatants and victims to citizens and community members, helping to dissolve conflict and build reconciliation and peace. As in Northern Ireland, such caring relations across community divides were crucial not only for everyday peace and conflict management, but also for keeping open the hope and the potential for large-scale, long-term peace and reconciliation. As elaborated below, similar inter-community relations are visible in Kashmir, albeit there, the everyday peace across communities is partly enabled by the lack of state care, and the communities' shared experiences of mistrust of the state.

\footnotetext{
42 Braithwaite (2014), 227.

${ }^{43}$ Braithwaite (2014); Siapno (2009); World Bank, 'GAM Reintegration Needs Assessment: Enhancing Peace through Community-Level Development Programming', http://documents.worldbank.org/curated/en/554011468259735196/GAM-reintegration-needsassessment-enhancing-peace-through-community-level-development-programming.

${ }^{44}$ In a survey, $76.7 \%$ of GAM indicated that such ceremonies had been held in their village. World Bank, op.cit, 25.
} 


\section{Kashmir: inter-and intra-communal care as fostering everyday peace ${ }^{45}$}

Kashmiris live in one of the world's most heavily militarised zones. ${ }^{46}$ The Indian state utilises the discourse of security to legitimise this status quo by constructing Kashmiris as a threat to the establishment of an increasingly Hinduising state. ${ }^{47}$ The present conflict with the Indian state dates back to late 1980s, three decades after Kashmir was annexed to India in $1948 .{ }^{48}$ Since then, the region has seen a spate of militant activities, demanding freedom from India. India has consistently responded with military force, ${ }^{49}$ often delegitimising these struggles as interference from Pakistan.

Unlike the other cases analysed in this article, the conflict in Kashmir is ongoing, and potentially expanding, to an extent that violence has become normalised. Yet, despite frequent eruptions of conflict and regular incidences of violence, mundane life goes on, as do everyday practices of relational care that maintain the possibilities of peace. Kashmiri Muslims of different denominations make up roughly $96 \%$ of the

45 This section draws on fieldwork carried out by Sanam Roohi in Srinagar during October 2016, with a brief follow up interviews in November 2017 in Bangalore. Interviews and group discussions were conducted with Muslims of different denominations, and Sikhs, when the town was undergoing intense and at times violent stand-off between the Indian State and the separatists, after a militant called Burhan Wani was killed by the armed forces in July 2016.

${ }^{46}$ According to verbal estimates, the Kashmiri conflict since 1948 has led to some 100,000 Kashmiris being killed, yet a more accurate figure is around 47,000 deaths since 1989 (see https://edition.cnn.com/2013/11/08/world/kashmir-fast-facts/index.html) often at the hands of the Indian security forces who are protected from prosecution under the Armed Forces Special Powers Act.

${ }^{47}$ For a detailed history of the Kashmiri struggle, see Mridu Rai, Hindu Rulers, Muslim Subjects: Islam, Rights, and the History of Kashmir (Princeton University Press, 2004).

48 A. G. Noorani, The Kashmir Dispute, 1947-2012 (Tulika Books, 2013) offers insight into the conflict as it stands today.

49 The Armed Forces Special Powers Act introduced in Kashmir in 1990 gives Indian army special powers to maintain law and order, often giving them indemnity from legal proceedings in case of excesses. 
population in the valley. While other communities like Hindus, Sikhs, and Buddhists form the remaining $4 \%$ of the population, ${ }^{50}$ these minorities are considered very important to the fabric of Kashmir as encapsulated through the term 'Kashmiriyat': a centuries old tradition of living together amidst religious diversity and peaceful coexistence among different religious groups. ${ }^{51}$ Looking at inter- and intra-community engagements in Kashmir among Kashmiri Muslims of different denominations and between Sikhs and Muslims, we show how relations of care provide momentary relief from conflict, making everyday life possible, and at times, even peaceful.

The state repression and violence against Muslims not only politicises the Muslim community, it simultaneously fosters intra-communal relations of care. Within this backdrop of historically problematic state-community relations, forging a solidary Muslim identity has brought the community together, often united against the ‘occupation’ of Indian state. Muslims may assert, for instance, that any person killed in a crossfire, or stone-pelting, whatever their religion, are their own sons and daughters. Hundreds and even thousands of Muslims attend the burial of these victims of state violence to mark their solidarity and protest. These instances show how the realm of care is by no means apolitical, but entangled with the socio-political circumstances where relations of care emerge - in this case as a community response and even as a form of resistance.

\footnotetext{
${ }^{50}$ During the height of Islamic militancy, some 100,000 Hindu Kashmiri Pundits left the valley in fear in 1990 and were settled in different parts of India, including Jammu region of the state of Jammu and Kashmir. Hindus were relocated in different parts of India and provided with affirmative actions and were often provided with government jobs. Yet a few thousand Hindus still remain in Kashmir today.

51 Puri, B. (1995). Kashmiriyat: the vitality of Kashmiri identity. Contemporary South Asia, 4(1), 55-63.
} 
While Muslims in Kashmir are divided in their political and sub-religious affiliations, the shared Islamic and place-based affinity allows for the creation of strong affective ties within the Muslim community across these and other divisions including gender. ${ }^{52}$ For instance, in 2016, during a shutdown and violence when the data for this case study was collected, a supporter of the People’s Democratic Party ${ }^{53}$ was visibly distressed to narrate how children were getting injured by the pellet guns used by security forces. He asserted that those getting injured are 'hamare bacchhe' or our children, and prayed for the use of pellet guns to stop. This example speaks to Ruddick’s emphasis that 'mothering' can be done by anyone taking responsibility for children’s lives. For the Muslim community, being exposed to state violence as a community, fostered intra-communal care relations, which are not limited to victims of violence. For instance, during the 2016 shut downs, villagers sent truckload of vegetables to the city to feed the inhabitants who were facing food shortages. Such relational ties, formed under the asymmetric threat from a common oppressor, holds social life in Kashmir together - helping to maintain everyday cordiality amongst Muslims, regardless of the social, political and other differences within the community. While such communal affinities may protract the conflict between the state and the community, in towns like Srinagar, these affinities create 'fictive' kinship ties that help make everyday life possible and, at times, peaceful.

Similar transformational potential is visible in inter-community relations of care. Research among Muslims and Sikhs in Kashmir shows that both communities' relations

\footnotetext{
52 Malik, Inshah. 2015. Imaginations of self and struggle: women in the Kashmiri armed resistance. Economic and Political Weekly. 50(49): 60-66.

53 The People's Democratic Party is the local ruling party in the state of Jammu and Kashmir, which has forged alliance with the Bharatiya Janata Party, the ruling Hindu right-wing party in India.
} 
with the state are undergirded with memories of violence and feelings of neglect. ${ }^{54}$ Therefore, pragmatism reigns, with an instrumentalist understanding of the Indian state. Sikhs have been making demands on the state for affirmative actions in the region given their minority status, without necessarily seeing the state as an ally. This neglect also unites the Muslims and Sikhs in their distrust of the state, which in turn fosters intercommunal relations of care, trust, and everyday peace.

Between the Muslim and Sikh communities, differences of opinion and suspicion based on political and other affiliations create mistrust. Yet, such mistrust can be offset by a strong sense of shared Kashmiri identity, irrespective of the religious or political affiliation. In the name of Kashmiriyat, or co-existence, people extend care to one another, and stories of everyday acts of care and concern between the communities abound. In the interviews, many Sikhs cited this reason behind their desire to continue living in the Muslim majority Kashmir, despite ongoing unrest and violence. While Muslims see Sikhs as an important part of their multi-ethnic social fabric, Sikhs are aware that the patronage of Muslims is vital for their survival as a minority community. Sikhs realise that Muslim violence is directed toward the state, and not aimed at them. Amongst the Sikhs interviewed for this research, stories of how Muslims and Sikhs have not had any instance of communal riots in the region was a common refrain. Sikhs also consider Kashmir a safe place, with less inter-personal violence, rape, thefts, and other crimes that plague the rest of India, and see it as an important reason for staying in Kashmir.

\footnotetext{
54 The desecration of golden temple and the anti-Sikh riots of 1984 following the then Prime Minister Indira Gandhi's assassination where officially 3,000 Sikhs were killed by Hindus, provoked by the Congress Party is a traumatic memory for the Sikhs.
} 
Sikhs and Muslims attend each other's weddings and funerals, provide social and psychological support as neighbours and respect each other's customs and taboos. Stories of Sikh families regretting their decision to relocate after 2008 or 2010 violence (between Indian security forces and Muslims) were also common. Additionally, stories about how Muslims have provided care to Sikhs in a 'big brotherly' manner thrive. For instance, one young Sikh man explained how Muslims always respected their religious sentiments. ${ }^{55}$ Another, much older man explained that when stone-pelting is on, no stone is pelted at Sikhs, and when they celebrate their festivals during times of violence, the stone-pelters give them way and allow their processions to pass peacefully. In addition, a 25-year old Sikh woman, a schoolteacher, spoke very warmly about the parents of her Muslim students. Another Sikh woman narrated that when a relative had unexpectedly required hospitalization in Srinagar, a Muslim family, whose ward was in the adjoining bed, came to their rescue, providing food and cash. The Sikh woman's slipper had broken in the rush to the hospital, and the Muslim lady gave the Sikh woman her slippers to go back home. ${ }^{56}$ These instances exemplify Kashmiriyat or Kashmiri ethics of care, which continues to build a sense of place, uniting the communities in Srinagar irrespective of their diverse religious identities, especially during the time of conflict.

In a place like Srinagar amidst an undeclared war between the Indian state and the people, conflict is externalized with the Indian state, and peace in the form of coexistence and provision of care is internalized, paving the way for life to 'go on.' Practices of caregiving both sustain life in a conflict situation and prevent communal enmity from becoming the defining feature of Muslim-Sikh relations, which protects

\footnotetext{
${ }^{55}$ Interview conducted on 12 November 2017 in Bangalore, India.

56 These interviews were conducted during October 2016.
} 
Kashmiriyat. As such, care practices are transformational. For the majority in Kashmir, internalized building of relations of care allow for not only relations and bonds of trust to deepen, but also for the potential for future peaceful coexistence, if Azaadi (freedom) is to be eventually realised in Kashmir.

From Kashmir, we now turn to the post-financial crash Iceland - a case, which would traditionally not be understood as a conflict in peacebuilding literature. Yet, shattering the economy, the crash (re)produced gendered structural violence, uncertainty, and precariousness, in similar ways as situations of direct violence do. Here, too, caring enabled life to go on.

\section{Iceland: The Women's Collective as care-givers in post-crash Reykjavík ${ }^{57}$}

The Icelandic economy was one of the earliest and most prominent victims of the financial crisis of 2008, also known as 'the great recession.' The country’s three largest banks, privatized only a few years earlier, had been aggressively internationalized. When combined, the three bankruptcies, which took place over the course of only ten days, rank as the third largest corporate bankruptcy in the world. ${ }^{58}$ As Iceland is one of the world's smallest sovereign countries, its residents felt the impact intensely.

A crisis of this magnitude could easily lead to civil unrest, and even violent conflict. Icelanders, however, do not have access to weapons; there is no military in the country and the police is mostly unarmed. Thus, when Icelanders gathered in October 2008 to protest their government's lack of response to these unprecedented events, the

\footnotetext{
57 This chapter is based on Silja Bára Ómarsdóttir participation in and notes from the Women’s Collective.

58 Jenny Anderson, ‘How Iceland Emerged from its Deep Freeze’, New York Times 3 July 2015. https://www.nytimes.com/2015/07/05/business/international/how-iceland-emerged-from-its-deepfreeze.html
} 
demonstrations were largely peaceful. A spontaneous organization, Raddir fólksins (i.e. The People's Voices) emerged to organize speakers around three main demands: the resignation of the government, the resignation of the boards of the Central Bank and the Financial Supervisory Authority (FME). ${ }^{59}$ These meetings were held from 11 October 2008 until 24 January 2009, ${ }^{60}$ when the government finally resigned on Monday, 26 January 2009. ${ }^{61}$

Concurrently with the People's Voices, a series of open meetings was held, ${ }^{62}$ where the organizers attempted to engage authorities with the public. Women’s movements criticized both series of meetings for promoting a masculine perspective on the crisis and responses to it. Iceland consistently ranks as one of the best places in the world to be a woman, ${ }^{63}$ but men were at the helm of all the banks, with a rare woman running the domestic side of the business. When the economy faltered, it was men who were profiled in the media, e.g. the rugged fishermen who left their homes and families behind and looked to the sea for survival. ${ }^{64}$ The international press focused on a different narrative, paying more attention to milestones of the reconstruction, such as a woman becoming prime minister, women elected to parliament in record numbers, and

\footnotetext{
${ }^{59}$ Baldur Arnarson, 'Reiðin ráði ekki för’, Morgunblaðið 30 September 2010. http://www.mbl.is/frettir/innlent/2010/09/30/reidin_radi_ekki_for/

${ }^{60}$ Raddir fólksins: ‘\#16 - Laugardagur 24. Janúar’ http://raddirfolksins.info/?cat=6\&paged=2

${ }^{61}$ Only in the week before, upon the first meeting of parliament after the Christmas break, did violence erupt, although some acts of sabotage had been registered before.

${ }^{62}$ Wikipedia.is, 'Opinn borgarafundur’, https://is.wikipedia.org/wiki/Opinn_borgarafundur. Accessed 15 May 2018.

63 Sigmarsdóttir, Sif, 'Once more, Iceland has shown it is the best place in the world to be female’, The Guardian 5 January 2018, https://www.theguardian.com/commentisfree/2018/jan/05/icelandfemale-women-equal-pay-gender-equality

${ }^{64}$ Charles Forelle, ‘As banking “Fairy-Tale” Ends, Iceland Looks Back to the Sea’. Wall Street Journal, 10 October 2008, https://www.wsj.com/articles/SB122359763876821355
} 
women taking over the hollowed-out banks ${ }^{65}$ - of which nothing remained but the domestic operations.

As the economy faltered, Icelanders were faced with significant uncertainty. The economy is heavily reliant on imports and with a suddenly worthless currency, supply lines closed on many companies and no one knew for how long. In economic downturns, women are usually the first to lose their jobs but in Iceland, it was the men, who were working in the high-risk side of the banking sector. Women had worked in the front-end positions that remained necessary for daily operations, very much fitting the narrative Prügl describes of the 'reckless man and responsible woman [that] offers insight into the unfamiliar of the crisis. ${ }^{, 66}$ This left women in Iceland, particularly in the urban area around Reykjavík, facing an even heavier second shift than before. Many women needed to find ways to meet the daily needs of their families on a single income, they could not be certain that they would have the same access to imported goods they used to have, and it was clear that the austerity policies would result in cutbacks of the welfare state. As Kantola and Lombardo note, the 'neoliberal policy solutions to the crisis ... require cutting down the public sector [and] tend to rely on and reproduce the gender roles that delegate major responsibility for care to women. ${ }^{67}$ It is in this context that a women's collective emerged, creating a feminist ethic of care in a precarious situation.

\footnotetext{
${ }^{65}$ Sunderland, Ruth, 'After the crash, Iceland’s women lead the rescue', The Guardian 22 February 2009, https:/www.theguardian.com/world/2009/feb/22/iceland-women

${ }^{66}$ Prügl, Elisabeth, “"If Lehman Brothers Had Been Lehman Sisters...”: Gender and Myth in the Aftermath of the Financial Crisis’, International Political Sociology 6:1 (2012), 21-35.

67 Johanna Kantola and Emanuela Lombardo, ‘Feminist Political Analysis: Exploring Strengths, Hegemonies and Limitations', Feminist Theory 18:3 (2017), 323-341.
} 
While many men lost their jobs, their voices were certainly not silenced. Noting that women were rarely heard in the post-crash environment, Reykjavík city councillor Sóley Tómasdóttir created a Facebook group, called ‘the women’s emergency government’ (Neyðarstjórn kvenna), and issued a manifesto for a women’s collective that would promote the reconstruction of a community based on humane values, emphasizing respect for the individual, community, life, nature and the environment. The collective declared that since men had so clearly been unable to develop a society that served the needs of the many, it was time for women to step forward. ${ }^{68}$ Within a few days, the group had grown to 1,600 members and expanded to 3,000 within a few weeks. Real-life meetings were planned and dozens of women attended the first brainstorming session on what could be done to ensure that women's voices would be heard and that women were not excluded from the reconstruction of Iceland's economy.

The women's collective developed organically. It tried to engage the political elite, get women active in politics and considered running a women's list for parliament, if and when elections would be called. In addition to political mobilization, an interesting response appeared in everyday acts of caring for each other. Women shared their willingness to teach each other skills that could be useful in a barter economy; they organized workshops on cutting hair, making new clothes from old ones, and so on. As many companies were going bankrupt, office buildings were left unoccupied and the group was given control over a bright and spacious office where women could spend their days working on creative projects and hold workshops. The space was operational for about a year, and contributed to the work of graphic designers, seamstresses, artists, web developers and more.

\footnotetext{
${ }^{68}$ Wikipedia.is: ‘Neyðarstjórn kvenna’ https://is.wikipedia.org/wiki/Ney\%C3\%B0arstj\%C3\%B3rn_kvenna. Accessed 15 May 2018
} 
The women's collective promoted a variety of causes over the 3-4 months it was most active, publishing three volumes of a newsletter that served as an outlet for women's views on the crisis. A simple four-page leaflet, each volume featured an interview with a woman, intellectuals and workers alike, commented on the gender bias of the media and the protests, and had a dedicated slot for a 'woman's soap box.'69

Inside and outside of the women's collective, people realized they needed to run their households differently, and started returning to more traditional foods. Lamb sales grew rapidly, ${ }^{70}$ and families started spending time together in preparing 'slátur,' a traditional liver sausage and blood pudding reminiscent of the Scottish haggis. Municipalities advertised community garden plots, available to anyone who was interested and many people started growing potatoes and root vegetables to supplement their families' diet and lowering the amount of money they spent on food. ${ }^{71}$ Knitting became popular again, as a way of earning money and calming the mind during this time of uncertainty. ${ }^{72}$ The traditional Icelandic woollen sweater 'lopapeysa' became a fashion statement and showed that the consumerism of the past years was

${ }^{69}$ Kvennastjórnartíðindi, 1:1 2008 https://rafhladan.is/bitstream/handle/10802/11466/1.\%20tbl.\%20\%20prent\%C3\%BAtg..pdf?sequence=2, Kvennastjórnartíðindi 1:2 2008 https://rafhladan.is/bitstream/handle/10802/11466/2.\%20tbl.\%20\%20prent\%C3\%BAtg..pdf?sequence=3, Kvennastjórnartíðindi 1:3 2008 https://rafhladan.is/bitstream/handle/10802/11466/3.\%20tbl.\%20\%20prent\%C3\%BAtg..pdf?sequence=4. Accessed 15 May 2018.

${ }^{70}$ visir.is ‘Stóraukin sala á lambakjöti’, 14 July 2010. http://www.visir.is/g/2010131785766. Accessed 15 May 2018.

${ }^{71}$ visir.is ‘Fleiri matjurtagarðar í sumar’ 29 January 2009. http://www.visir.is/g/2009178508607. Accessed 15 May 2018.

72 Rannveig Karlsdóttir, ‘Að prjóna saman samfélag: Hlutverk og gildi handverks eftir bankahrunið árið 2008', MA Thesis in Ethnology, University of Iceland. 2014. https://skemman.is/bitstream/1946/17879/1/A\%C3\%B0\%20prj\%C3\%B3na\%20saman\%20samf\%C 3\%A9lag.pdf 
disappearing. ${ }^{73}$ In this way, women took on the role of constructing a new national identity through protecting and transmitting culture and values, but also by contesting what had been the dominant national project. $^{74}$

The women's collective faded quickly. In January of 2009, the government resigned and elections were scheduled for the spring. With elections set so soon, many women returned to the political parties they had been active in - in particular the two left-wing parties, both of which identified as feminist. Some women remained true to the collective and attempted to organize a run for parliament, with the caveat that they would first pressure the established parties to ensure equal representation of women and men. ${ }^{75}$ The attempt fizzled and did not result in a women’s list in the April 2009 elections.

It is true that the women's collective did not bring about a revolutionary change in the political system. However, offering a 'strategy for organizing, ${ }^{76}$ the collective's impetus on caring was transformational in the time of the crisis. It awakened a sense of care with the women who participated in it, and in the wider society. Political ambitions for the women's collective faltered, the focus on caring for each other and the community, which members perceived as needing support rather than a struggle, resulted in confidence building and trust towards one another. Through their organising

\footnotetext{
${ }^{73}$ Karlsdóttir (2014).

${ }^{74}$ Umut Erel, 'Saving and reproducing the nation: Struggles around right-wing politics of social reproduction, gender and race in Austerity Europe’, Women's Studies International Forum (in press). https://doi.org/10.1016/j.wsif.2017.11.003; Nira Yuval-Davis, 'Women, Citizenship and Difference’, Feminist Review 57 (1997), 4-27

${ }^{75}$ Morgunblaðið, 'Verði prýstiafl á stjórnvöld’, 14 March 2014. https://www.mbl.is/frettir/innlent/2009/03/14/verdi_thrystiafl_a_stjornvold/. Accessed 15 May 2018

76 Tronto (1993), 175.
} 
and caring practices, women were able to rely on one another for support. The trust they built through care enabled many women to get by, emotionally and financially. By focusing their energy on constructive projects in the midst of a crisis, the women engaged their neighbours, colleagues and peers in a network to build a stronger and more cohesive community.

\section{Concluding remarks}

Our different case studies contribute to the discussions on everyday peace that argue against universally applicable schemas of peacebuilding, calling attention to the geopolitical, historical, and socio-cultural specificities of conflicts. We build upon a long tradition of feminist peace research that since the 1980s has examined how everyday practices of care give rise to alternative moral and political thinking, while feeding into alternative practices of conflict resolution. We argue that the care lens promoted by this tradition is pivotal for a fuller picture of the conditions and practices of peacebuilding within and across communal divides.

We show how different gendered forms of caring shape the political space in the midst of conflicts. In all the cases, relations of care emerge as a dynamic for processes of trust-building, community-building, and peaceful transformation. We began with an analysis of women's community groups' work in Northern Ireland. This case draws attention to the relational logic that led women from both sides of the conflict to take over several organisational tasks of care, when the state structures failed, and how these shared activities helped to breach inter-communal divides, creating spaces for everyday peace. Drawing attention to the care activities in Aceh carried out by men in patriarchal environments, we argue that regardless of the temptation to read such acts as instances of patriarchal governance, reading them as gendered care helps to understand how different kinds of caring relations work for everyday peace. 
The case of Kashmir, in turn, illuminates the ways in which conflicts may foster inter- and intra-communal care relations amongst and within ethnic groups differentially affected by state-led violence. A shared place-based affiliation to Kashmiriyat encourages relations of care, which in turn create possibilities for peace and coexistence in an intensely strife ridden zone. Post-financial crash Iceland would traditionally not be understood as a conflict. Yet, the shattered economy (re)produced gendered structural violence, overshadowed by the voices of (elite) men. To this, women responded by organising joint caring activities that contribute to a more stable and cohesive community.

These four cases exemplify, how feminist care ethics as a theory of human relationality adds to our understanding of everyday peace. This does not mean that care should be romanticised as eternally peaceful human activity, or that carers should be automatically read as peacemakers. Rather, caring, while embedded in gendered relations of power, continues to manifest itself beyond the intimate practices of caregiving. For better 'post-liberal' practices of peacebuilding, we argue that it is crucially important to read human relatedness and subjective action as practices of caring. Indeed, understanding particular relations and practices of care as everyday peacebuilding helps us to better comprehend the localised and particular needs of people - that is, the everyday sources of suffering and deprivation - that must be responded with care, in order for trust and peaceful transformation to emerge.

Our suggestion to pay attention to care in peacebuilding, and account for the feminist peace research tradition, is fully compatible with most critical accounts of everyday peace. Indeed, we argue that the care lens complements critical peace studies in important ways. By resolving conflicts over immediate care needs and building the capacity of communities in ways that subtly challenge the fixity of conflict, care 
cumulatively creates possibilities for peaceful transformation. Therefore, it is crucially important to ask, not only in feminist accounts but in all contexts of peacebuilding: how care is present, what kind of care is present, and what particular relations of care do for everyday peace and the potential for transformation in conflict and post-conflict societies. If we do not address these questions, we cannot claim to understand, what it takes to sustain life during conflicts, and in their aftermath. For life does not go on without the varied gendered dimensions of care and caring. 